International Journal of Agriculture, Environment and Bioresearch

Vol. 5, No. 03; 2020

ISSN: $2456-8643$

\title{
VARIABILITY IN LENGTH OF RAINY SEASON FOR SELECTED CROPS PRODUCTION IN COASTAL AND UPLAND AREAS OF AKWA IBOM STATE, NIGERIA
}

\author{
A.I. Isaiah ${ }^{1 *}$, A.M. Yamusa ${ }^{2}$ and A.C. Odunze ${ }^{1}$ \\ ${ }^{1}$ Department of Soil Science, Faculty of Agriculture, Ahmadu Bello University, Zaria - Nigeria. \\ ${ }^{2}$ Meteorological Unit, Department of Soil Science, Institute for Agricultural Research, Ahmadu Bello University, \\ Zaria - Nigeria \\ https://doi.org/10.35410/IJAEB.2020.5517
}

\begin{abstract}
This study assessed variability of rainfall in coastal and upland areas of Akwa Ibom State, as a guide for cultivation of maize, tomato, yam, cassava, oil palm and cocoa in the areas. The study was done in four different locations - coastal areas (Eket and Oron) and upland areas (Uyo and Ikot Ekpene). Daily rainfall data were obtained from Nigeria Meteorological Agency (NiMet), Abuja, for a period of 30 years (1989 - 2018). The amount of annual rainfall was determined using descriptive statistics; percentage of rainfall distribution was determined using precipitation concentration index equation; and onset, cessation and length of growing season were determined using Instat+ 3.36 software. The annual rainfall shows high variability between coastal and upland areas. Coastal areas experienced high amount of rainfall with average annual rainfall of $3282.50 \mathrm{~mm}$ (Eket) and $3094.87 \mathrm{~mm}$ (Oron); while the average rainfall for upland areas were $2272.24 \mathrm{~mm}$ (Uyo) and $2007.49 \mathrm{~mm}$ (Ikot Ekpene). All the areas experienced moderate precipitation distribution with coastal areas - Eket (11.31\%) and Oron (11.67\%); upland areas - Uyo (12.67\%) and Ikot Ekpene (13.70\%). Coastal areas (Eket and Oron) recorded early onset, late cessation and long length of growing season than upland areas (Uyo and Ikot Ekpene). The mean onset for Eket and Oron were 19th and 21st February; cessation 4th and 1st December and length of growing season 289.0 and 283.5 days respectively. The mean onset for Uyo and Ikot Ekpene were 8th and 17th March; cessation 16th November and 12nd November and length of growing season 265.2 and 255.3 days respectively. The study shows that only upland areas can support sustainable production of yam and cassava, while both upland and coastal areas can support sustainable production of oil palm and cocoa. Also, sustainable production of tomato and maize production may not be achieved in both areas.
\end{abstract}

Keywords: Crop production, rainfall characteristics, rainy season, rainfall variability, sustainability.

\section{INTRODUCTION}

Rainfall is the common source of moisture for agricultural production especially for farmers in rainforest zone where there is no irrigation facilities. It is a vital and valuable natural resources 
that support lives (Gadgilet al., 1998; FAO, 1996). Rainfall variability is the degree to which onset, length of growing season, cessation, amount and distribution of rainfall varies across an area due to climatic influence (Reprah 2012). Variation in rainfall is the characteristics of climate and possess a great threat to agricultural production. The amount of moisture present in soil for plant use depends on onset of rainfall, cessation and length of growing season which affect the success/failure of crops. The proper study and understanding of rainfall variability will help farmers in determining the type of crops to cultivate and time of planting (Laux, 2009).Therefore, this study was to assess onset, length of growing season and cessation of rainfall for the cultivation of maize, tomato, yam, cassava, cocoa and oil palm in Akwa Ibom State.

\section{MATERIALS AND METHODS}

\section{Description of the study area}

The study was conducted in Akwa Ibom State in four local government area; two each from upland and coastal areas; i.e. coastal areas (Eket and Oron) and upland areas (Uyo and Ikot Ekpene). Akwa Ibom State lies between longitudes 7025' and 8025'E and latitudes 4032' and 5030 'N. It has a humid tropical climate, characterized by distinct wet and dry seasons. Annual rainfall varies from $3,000 \mathrm{~mm}$ along the coast to $2,250 \mathrm{~mm}$ in the northern fringe. Temperature values are relatively high in Akwa Ibom State throughout the year with mean annual values varying between 26 and $28^{\circ} \mathrm{C}$. Also, relative humidity remains at average of $70-80$ percent throughout the year. Average sunshine circulates to 1,450 hours per year and the annual evaporation rate range from 1,500 - $1800 \mathrm{~mm}$ (Ekpeyong, 2013). 
International Journal of Agriculture, Environment and Bioresearch

Vol. 5, No. 03; 2020

ISSN: $2456-8643$

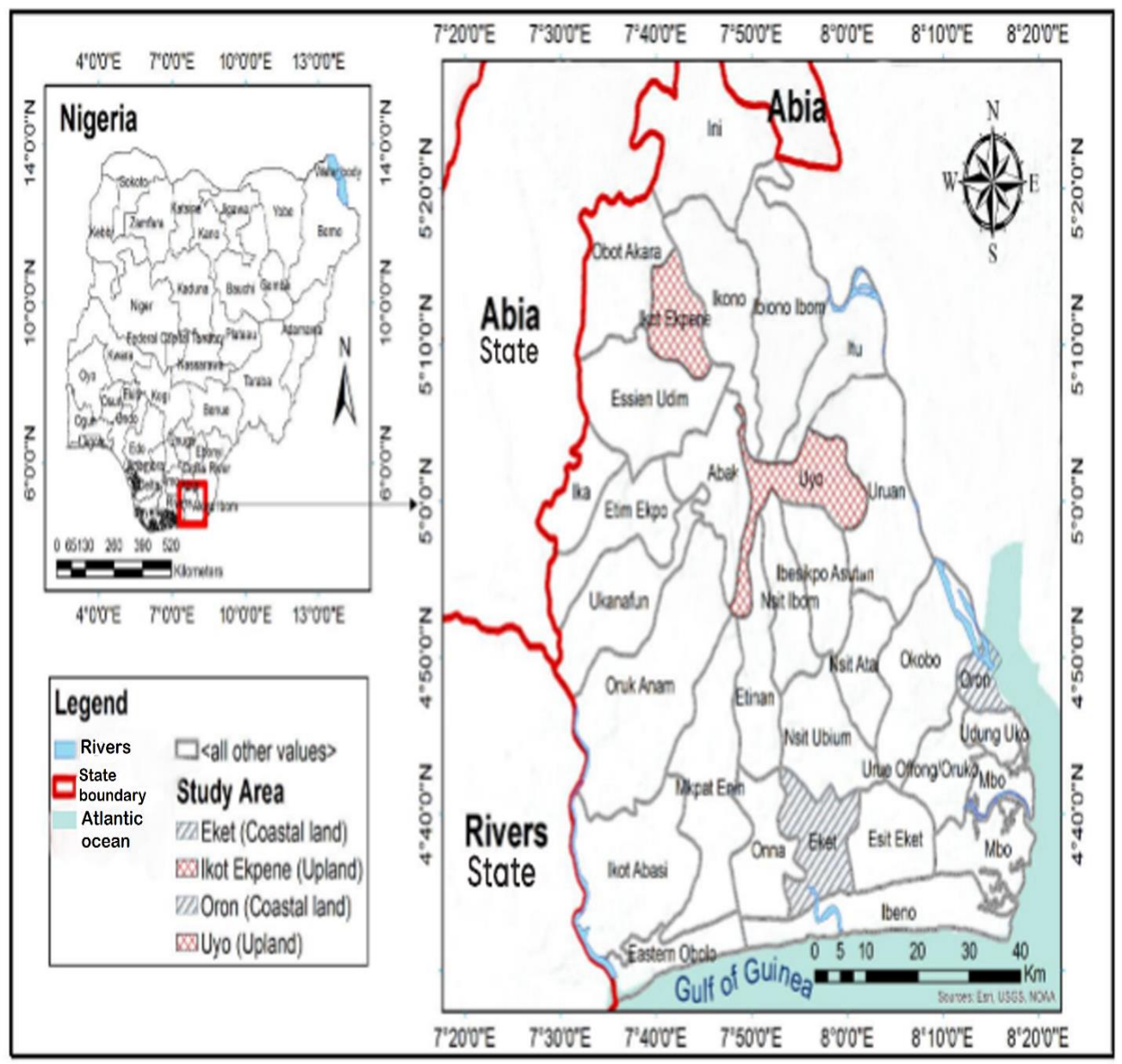

Fig.1: Akwa Ibom State showing the study area

\section{Data collection}

The daily rainfall of Uyo and Ikot Ekpene (i.e. for upland areas) and that of Eket and Oron (i.e. coastal areas) were collected at Nigeria Meteorological Agency (NiMet), Abuja, for a period of 30 years $(1988-2018)$ 
Table 1 Geographical Characteristics of the Weather Stations

\begin{tabular}{lllc}
\hline Location & Latitude & Longitude & Elevation $(\mathrm{m})$ \\
\hline Eket & $04^{0} 38^{\prime} 47.43^{\prime \prime} \mathrm{N}$ & $07^{0} 58^{\prime} 00.20^{\prime \prime} \mathrm{E}$ & 17.67 \\
Oron & $04^{0} 48^{\prime} 27.24^{\prime \prime} \mathrm{N}$ & $08^{0} 15^{\prime} 00.52^{\prime \prime} \mathrm{E}$ & 30.16 \\
Uyo & $05^{0} 30^{\prime} 45.36^{\prime \prime} \mathrm{N}$ & $07^{0} 55^{\prime} 56.16^{\prime \prime} \mathrm{E}$ & 54.23 \\
Ikot Ekpene & $05^{0} 11^{\prime} 22.39^{\prime \prime} \mathrm{N}$ & $07^{0} 42^{\prime} 55.40^{\prime \prime} \mathrm{E}$ & 70.10 \\
\hline
\end{tabular}

Source: NiMet, 2018

\section{Statistical Analysis}

The amount of annual rainfall was determined using descriptive statistics; percentage of rainfall distribution was determined using precipitation concentration index equation; and onset, cessation and length of growing season were determined using Instat+ 3.36 software.

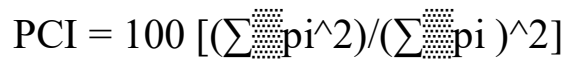

Where:

$\mathrm{Pi}=$ rainfall amount of the ith month

$\mathrm{i}=$ January ... December

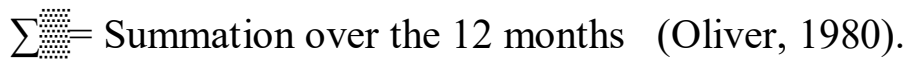

Table 2: Precipitation Concentration Index (PCI) Range and Classification

\begin{tabular}{cc}
\hline PCI Value & Classification \\
\hline$\leq 10$ & Uniform Precipitation Distribution \\
$10-15$ & Moderate Precipitation Distribution \\
$16-20$ & Irregular Precipitation Distribution \\
$>20$ & Strong Irregular Precipitation Distribution \\
\hline
\end{tabular}

Source: Oliver, 1980

\section{RESULTS AND DISCUSSIONS}


From Table 3, mean annual rainfall for Eket, Oron, Uyo and Ikot Ekpene are $-3282.50 \mathrm{~mm}$, $3094.84 \mathrm{~mm}, 2272.24 \mathrm{~mm}$ and $2007.49 \mathrm{~mm}$ respectively; standard deviation are $-645.45 \mathrm{~mm}$, $569.04 \mathrm{~mm}, 302.23 \mathrm{~mm}$ and $299.60 \mathrm{~mm}$ respectively; and coefficient of variance are $-19.67 \%$, $18.34 \%, 13.30 \%$ and $14.92 \%$. The result shows great variation between the coastal and upland areas. The coastal areas recorded higher amount of rainfall than upland areas. The highest mean annual rainfall of $3282.50 \mathrm{~mm}$ was recorded in Eket (coastal area), and least mean annual rainfall of $2007.49 \mathrm{~mm}$ was recorded in Ikot Ekpene (upland). The variation in rainfall between coastal and upland areas may be attributed to climate change, topography, moisture build up and continentality (Umoh, 2009). Omotosho et al., (2000) reported a rapid increase in annual rainfall in coastal regions due to climate change through the continuous emission of greenhouse gases into atmosphere leading to the depletion of ozone layers. Also, all the areas experienced moderate rainfall distribution with Eket, Oron, Uyo and Ikot Ekpene recorded 11.31\%, 11.67\%, $12.67 \%$ and $13.70 \%$ PCI respectively. This shows that areas witness single rainy season (Oliver, 1980).

From the result in Table 4, mean onset, cessation and length of growing for Eket were recorded on 19th February (50.2 days), 4th December (339.5 days) and 289.2 days respectively. The mean onset, cessation and length of growing season for Oron were recorded on 21st February (52.1 days, 1 st December (335.6 days) and 283.5 days respectively. The mean onset, cessation and length of growing season for Uyo were recorded on 6th March (65.8 days), 16th November (321.1 days) and 265.2 days respectively. The mean onset, cessation and length of growing season for Ikot Ekpene are recorded on 17th March (76.8 days), 12th November (317.3 days) and 255.3 days respectively. Coastal areas of Eket and Oron recorded earliest onset, late cessation and longest length of growing season, while upland areas of Uyo and Ikot Ekpene recorded late onset, earliest cessation and shortest length of growing season. The variation in onset, cessation and length of growing season recorded between coastal areas and upland areas, may be attributed to proximity to water bodies (continentality) Omotosho et al., (2000).

Figure 2 show the trends of rainfall onset in coastal and upland areas. All areas indicate negative trends. In Eket $-\mathrm{r}^{2}=0.2546$ and $\mathrm{y}=-0.7811 \mathrm{x}+45080$; Oron $-\mathrm{r}^{2}=0.2646$ and $\mathrm{y}=-0.6024 \mathrm{x}+$ 4459 ; Uyo $-r^{2}=0.2391$ and $y=-0.511 x+4459$ and Ikot Ekpene $-r^{2}=0.2146$ and $y=-0.5473 x$ +14463 . These show that onset of rainfall is moving from March to February in upland areas and February to January in coastal areas. Laux et al., (2009) stated that rainforest zone and other wet tropical areas will continue to experienced shift in rainfall onset toward the beginning of the year (i.e. January) especially in coastal areas than upland areas due its proximity to water bodies.

Figure 3 show cessation of rainfall in coastal and upland areas. From the trends, it indicates increase in cessation in all areas. In Eket $-r^{2}=0.3974$ and $\mathrm{y}=0.8765 \mathrm{x}+42047$; Oron $-\mathrm{r}^{2}=$ 0.438 and $\mathrm{y}=1.0011 \mathrm{x}+41794$; Uyo $-\mathrm{r}^{2}=0.5135$ and $\mathrm{y}=0.7172 \mathrm{x}+42348$ and $\mathrm{r}^{2}=0.645$ and $\mathrm{y}$ $=0.9424 \mathrm{x}+41894$. The trends vary between October and November in upland areas and November and December in coastal areas. This shows that upland areas experienced early cessation than coastal areas. The variation in cessation may be attributed to climate change. Cessation, which mark the end of rainy season influence length of growing season. Late cessation leads to increase in length of growing season and vice visa. (Leonard et al., 2015). 
Figure 4 show trends of length of growing season in coastal and upland areas. All areas experienced increase in length of growing. In coastal areas of Eket and Oron $r^{2}=0.53(53 \%)$ and $\mathrm{y}=1.6358 \mathrm{x}+298.8 ; \mathrm{r}^{2}=0.52(52 \%)$ and $\mathrm{y}=1.6305 \mathrm{x}+298.6$ respectively while in upland areas of Uyo and Ikot Ekpene $\mathrm{r}^{2}=0.50(50 \%)$ and $\mathrm{y}=1.1987 \mathrm{x}+214.7 ; \mathrm{r}^{2}=0.49(49 \%)$ and $\mathrm{y}$ $=1.398 x+256.4$ respectively. This shows that coastal areas experienced longer length of growing seasons than upland areas.

\section{Crops water requirement and rainfall variability}

In crop production, understanding crops water requirement and their maturity periods are vital for its sustainable. Crop yield and water are inextricably link; and rainfall is the major source of moisture for crop production (Ezenwaji and Nzoiwu, 2016).

The average annual rainfall require for maize, tomato, cassava and yam are $500-800 \mathrm{~mm}, 400-$ $600 \mathrm{~mm}, 1200-2300 \mathrm{~mm}$ and $1000-2250 \mathrm{~mm}$ respectively (FAO, 2013). Hence, sustainable maize, tomato, cassava and yam production cannot be achieved in coastal areas of Eket and Oron since average annual rainfall in these areas are more than its water requirement, needed for their growth and development (as indicated in Table 3). Stewart and Nielsen (1990), reported that high amount of rainfall has adversely affects the growth of young tomatoes seedlings and probably predisposes plants to invasion by soil fungi capable of causing seed rot and seedling blight. In addition, it slow down germination and pollination process in maize and tomato, causing irreparable harm to the delicate structures of emerging maize seedlings. It restricted root growth causing a build-up of sugars in the maize leaf. These sugars would normally be used for root and shoot growth, but when accumulated in the leaf, it would result in the production of anthocyanins, which give the leaf a purple colour (Lizaso and Ritchie, 2007). Moreover, in upland areas of Uyo and Ikot Ekpene, sustainable yam and cassava production could be achieved in these areas since the average annual rainfall falls within the range which the crops can thrive well. On the other hand, oil palm and cocoa that require annual rainfall of $2000-3500 \mathrm{~mm}$ and 1,500 - 3,250 mm respectively (Bello et al., 2015; Olomola et al., 2003), could survive in both upland and coastal areas of the Akwa Ibom State since the average annual rainfall in these areas fall between the range of these crops water requirement (as indicated in Table 3). Ndon (2006), reported that oil palm, cocoa and other tree crops has the capacity to tolerate high amount of rainfall more than the short duration crops (like maize, wheat, tomato, melon, sorghum, etc.) and tuber crops, since these are perennial crops and have medium potential for storing excess water (i.e. large body size, leaves, etc.).

\section{CONCLUSION}

Climate variability is a serious environmental issue that possess great threat to sustainable development and food security. Therefore, to avert the risks of crops failure, poor yield and economic loss, the use of seasonal climate outlook is recommended for adjusting farm operations and farming system decisions. 
International Journal of Agriculture, Environment and Bioresearch

Vol. 5, No. 03; 2020

ISSN: $2456-8643$

Table 3: Variation of rainfall in some selected areas of Akwa Ibom State (1989 - 2018)

\begin{tabular}{lcccc}
\hline Location & Mean Rainfall $(\mathrm{mm})$ & Standard deviation $(\mathrm{mm})$ & $\mathrm{CV}(\%)$ & PCI(\%) \\
\hline Eket & 3282.50 & 645.45 & 19.67 & 11.31 \\
Oron & 3094.84 & 569.04 & 18.34 & 11.67 \\
Uyo & 2272.24 & 302.23 & 13.30 & 12.67 \\
Ikot Ekpene & 2007.49 & 299.60 & 14.92 & 13.70 \\
\hline
\end{tabular}

Table 4: Mean onset, cessation and length of growing season (LGS)

\begin{tabular}{|c|c|c|c|c|c|c|}
\hline \multirow[t]{2}{*}{ Location } & \multicolumn{2}{|c|}{ Onset } & \multicolumn{2}{|c|}{ Cessation } & \multicolumn{2}{|c|}{ LGS } \\
\hline & Days & Date & Days & Date & Days & Months \\
\hline Eket & 50.4 & $19^{\text {th }}$ February & 339.5 & $4^{\text {th }}$ December & 289.0 & 10 \\
\hline Oron & 52.1 & $21^{\text {st }}$ February & 335.6 & $1^{\text {st }}$ December & 283.5 & 10 \\
\hline Uyo & 67.0 & $08^{\text {th }}$ March & 321.1 & $16^{\text {th }}$ November & 265.2 & 9 \\
\hline IK. EK. & 76.8 & $17^{\text {th }}$ March & 317.3 & $12^{\text {th }}$ November & 255.3 & 9 \\
\hline
\end{tabular}

IK. EK=IkotEkpene

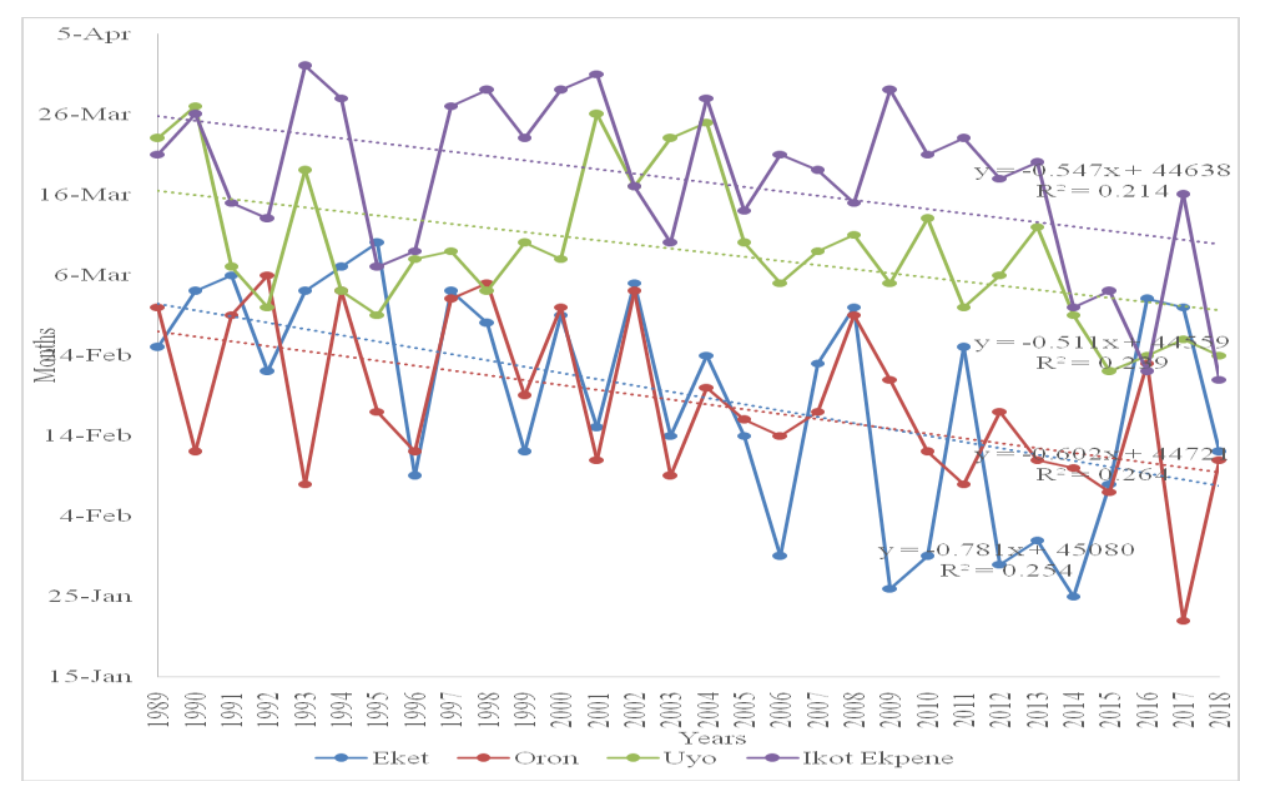

Fig. 2: Onset of rainfall for Eket, Oron, Uyo and Ikot Ekpene (1989 - 2018) 
International Journal of Agriculture, Environment and Bioresearch

Vol. 5, No. 03; 2020

ISSN: $2456-8643$

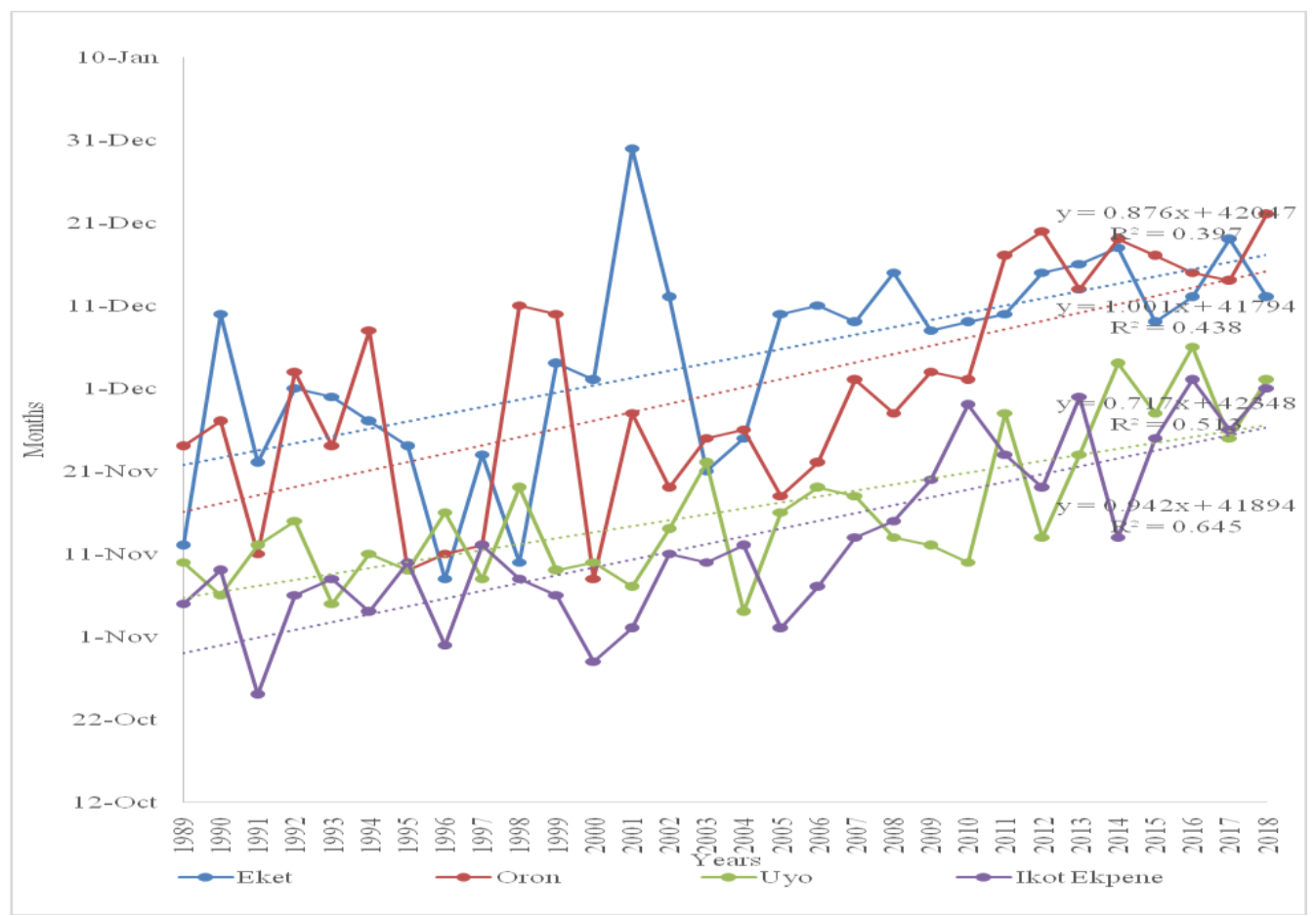

Fig. 3: Cessation of rainfall for Eket, Oron, Uyo and Ikot Ekpene (1989 - 2018) 
Vol. 5, No. 03; 2020

ISSN: $2456-8643$

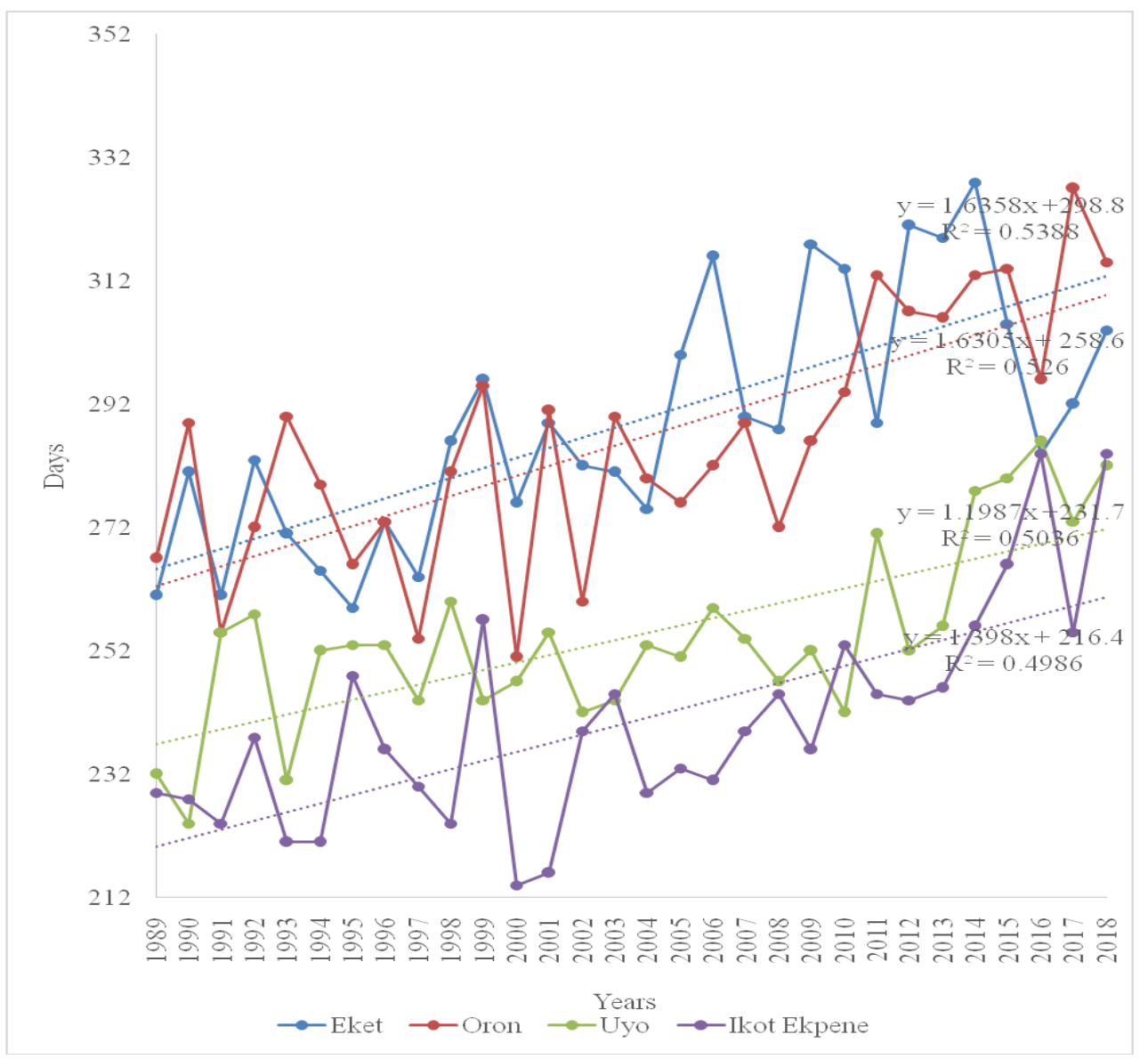

Fig 4: Length of growing season for Eket, Oron, Uyo and Ikot Ekpene (1989 - 2018)

\section{REFERENCE}

Bello, R. S., Bello, M. B., Essien, B. A. and Saidu, M. J. (2015). Economic potentials of oil palm production and machinery use in Udi, Enugu State, Nigeria. Science Journal of Business and Management Volume, 3(5)16-20.

Ekpenyong, R. E. (2013). Assessment of the threat to global warming in Akwa Ibom State, Nigeria. Journal of Environmental Management and Public Safety, 2(2), 065 - 074.

Ezenwaji, E. E.1, Nzoiwu C. P. (2016) Analysis of Precipitation Concentration (PCI) for Awka Urban Area, Nigeria. Proceeding of 2016 International Conference \& 30th Annual General Meeting of the Nigerian Meteorological Society, held in Federal University of Agriculture Abeokuta, Nigeria, 21st - 24th November, 2016.

Food and Agricultural Organization (FAO) (1996). Control of water pollution from agriculture. FAO irrigation and drainage Paper55, FAO, Rome, pp. 101. 
Food and Agricultural Organization of the United Nations (FAO) (2013). FAOSTAT Database. Available at: http://bit.ly/NmQzZf.

Gadgil, S., Seshagiri, P. R., and Sridhar, S. (1998). Modeling impacts of climate variability on rainfed groundnut, Bangalore, India. Indian Institute of Science. pp: 11.

Laux, P., Jackel, G., Tingem, M. and Kunstmann, H. (2009). Onset of the rainy season and crop yield in sub-Saharan Africa - Tools and perspectives for Cameroon ecohydrology of surface and groundwater dependent systems: Concepts, Methods and Recent Developments, pp. $238-338$.

Lizaso, J. I. and Ritchie, J. T. (2007). Maize shoot and root response to root zone saturation during vegetative growth. Journal ofAgronomy, 89:125-134.

Ndon, B. A. (2006). The Oil palm: Economic palm series.Concept publications, Lagos, Nigeria pp. 78 - 98.

Nigerian Meteorological Agency (NiMet) (2018). Seasonal rainfall prediction. Annual publication of Nigerian Meteorological Agency (NiMet) Abuja, pp. 23 - 34

Oliver, J. E. (1980). Monthly precipitation distribution: A Comparative index. Professional Geographer, 32:300 - 309.

Olomola, A. C. Nwosu, B. A. Oni, S. O. Akande and Akanji, B. O. (2003). Prospects for increased value-added in Nigeria cocoa exports. NISER Monograph.

Omotosho, J. B. Balogun, A. A. and Ogunjobi, K. O. (2000): Predicting monthly and seasonal rainfall, onset and cessation of the raining season in West Africa using only surface data. International Journal of Climatology, 20: $865-880$.

Reprah, K. (2012). Rainfall and comparative correlation with crop yield: The case of Asunafo Forest, Ghana. International Journal of Science and Research, $319-453$.

Umoh, E. (2007), "Flooding problems in Rivers State", Journal of Environmental Science, $4(2): 44-60$. 